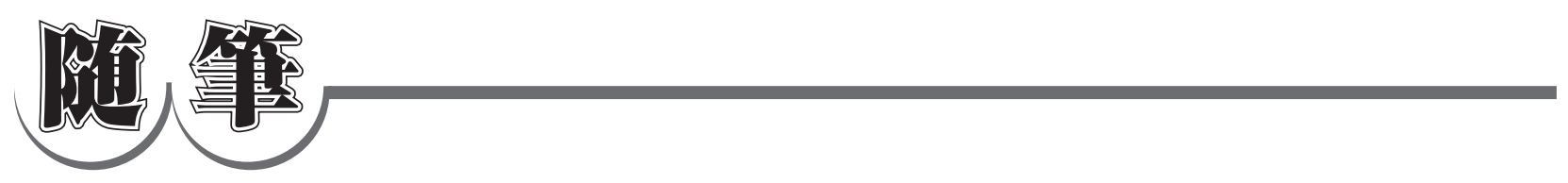

\title{
Made in Japan*
}

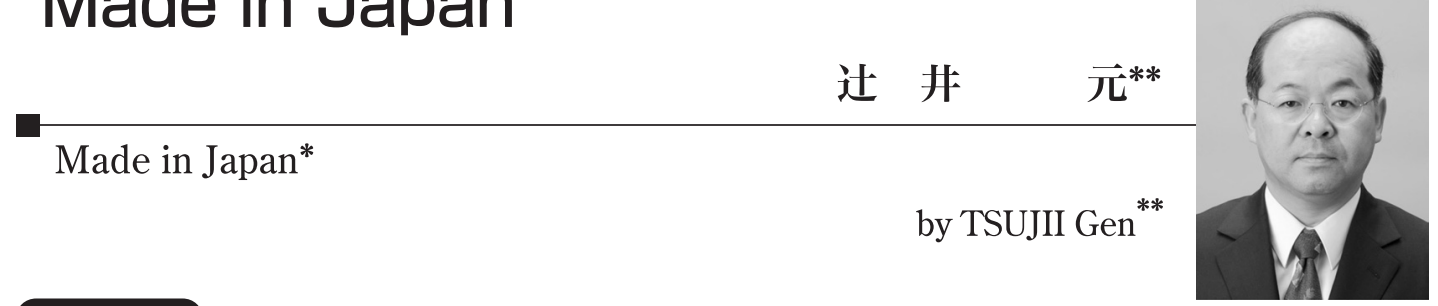

キ一ワード モノ作り，米国製造業，技術伝承，技能伝承，産官学，教育，人材育成

昨年， 7 年間の米国駐在から帰国しました。日本を外 から見る機会を得て，7 年間の異文化体験から日本のモ ノ造りについて感じるところを書いてみたいと思います。 私の米国との係わりは，ホンダが日本の同業他社に先 駆けて 1982 年に立ち上げたオハイオ州メアリスビルに立 地する自動車製造会社 Honda of America Mfg. Inc. (写真 1 ）の建設プロジェクトに参画したことでした. 先行し て二輪車の生産を始めていたとはいえ, 初めて製造業に たずさわるオハイオの人々を, 教育してきちんとした品 質の車を作るという仕事でした。オハイオで採用した 人々の中から核となる人々を埼玉製作所狭山工場に集め てのパーソンツーパーソンでの現場作業, 保全業務, 品 質管理，管理業務などの教育は日米双方のメンバーにと っては，言語の壁や文化の壁を乗り越えた上でのモノ造 り研修であり，大変なことだったように思います。こう した努力もあって, 計画通りに生産 1 号車をラインオフ し (写真 2$)$, 何年経ったら黒字になるのかという当初の 危惧を他所に，生産した車は飛ぶように売れ，増産につ ぐ増産という状況が続きました。

1980 年代のアメリカは鉄鋼, 電気, 自動車を始めとす る産業界のパフォーマンス低下が問題となっていた一方 で，アメリカに進出した日系企業のトランスプラントが 次々に好業績をあげていたことから，いろいろな調査が 行われました。その中で, マサチューセッツ工科大学 (MIT) のポール・グレイ総長が問題提起した「アメリカ 産業の業績に生じた異変は何か」・「事態の打開と改革の ためにアメリカができることは何か」の 2 点を調査した 結果が,「Made in America」という表題で 1990 年に日米 同時出版されたので，読まれた方も多いと思います. $\lceil$ Made in America」の中では「より一層生産的で世界経 済のリーダーである新しいアメリカ」というビジョンが 描かれ，それを達成するための数々の提言がなされてい ます。それまで重視されていた財務, 経理, 事業企画と いった業務よりも，製品，技術，生産プロセスを重視す る必要性が主張され, 産業界, 労働組合, 政府, 教育機 関がいかに変わるべきか，いかなる戦略をとるべきかが

\footnotetext{
原稿受付 平成 19 年 9 月 6 日

ホンダエンジニアリング(株） 本田技研工業(株)

Honda Engineering Co., Ltd. Honda Motors Co., Ltd.
}

提言されています.

この提言の後, いろいろな改革の努力が実際に行われ たようです。私はこの起点となった MITを1993年に訪 れましたが, “Manufacturing science”を標榜し, 科学 (Science) よりも生産・製造（Manufacturing）に対して 学生が興味を持つようにカリキュラムを変えたり, 工場 での実地体験をカリキュラムに組み达んだりしていまし た。またミシガン大学では MRC (Manufacturing Research Center) と称して, 例えば長持ちする機械加工 用刃具の刃先形状の研究など泥臭く製造現場の改善テー マに取組んでいる事例も見ました．もちろん，この提言 だけで全てのアメリカが変わったとは言えないでしょう が, 産官学挙げてのダイナミックな改革の波にアメリカ
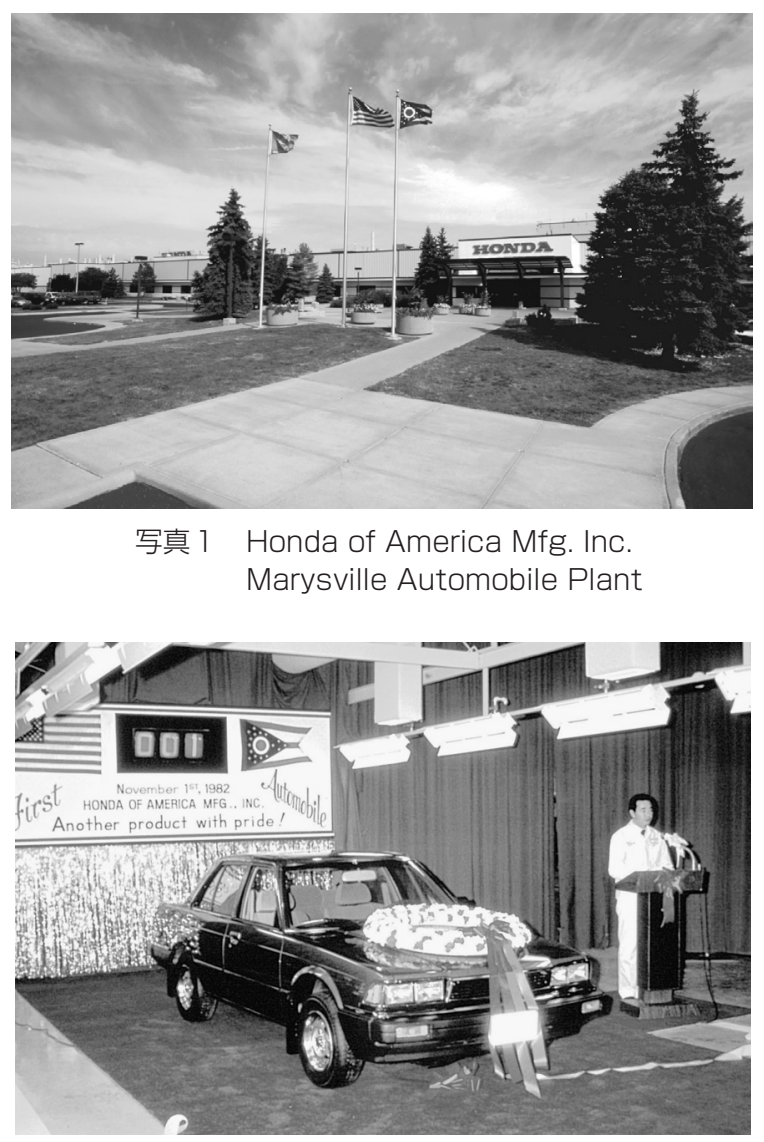

写真 2 北米生産 1 号車のアコード·セダン 
の底力を感じたものでした。その後の日本や東南アジア 経済のリセッションなど経済環境の変化の影響も考えら れるでしょうが，意気消沈していたアメリカの製造業が 1990 年代には「強いアメリカ」に変身した陰には改革へ の強い意思と不断の努力があったはずです．特に重点施 策が「教育・人材育成」であったことが大きな要因だっ たと思います．最近の米国製造業の海外シフトをみると， また改革の時期なのかという感もありますが，改革の背 景と目的が共有化されるとドラスティックな動きを見せ る大変ダイナミックな国であることは間違いないと思い ます。ホンダの北米工場に入社した新人スタッフを見て も，現場で即戦力として使えるようなスキルを学校で身 につけてきている人が多く，実践的な教育を受けてきて いるように感じました。学生時代の製造業体験実習で, 製造業の「仕事」を理解して，具体的にこんな仕事をし てみたいという明確な目的意識を持った人が多くいたよ うに感じました。

一方，日本の製造業では90年代初頭のバブル経済崩壊 以降，出口を求めての模索がまだ続いているように思い ます．改革を叫ばれながら産官学それぞれがなかなか大 きく変われないままでいます。製造業では，モノ造りを 支える現場力の強化や技術・技能伝承が大きな課題とし て声高に聞かれるようになりました。縮小均衡を狙った 組織・構造改革, 海外・社外生産へのシフトや従業員新 規採用の抑制と正規外従業員の拡大などが進んだ結果と して，技術者・技能者の高齢化が進み，昨今の少子化の
動向もあって後継者が無くて伝承に困っているという企 業が多いようです，好況な業種では，最近のグローバル な事業拡大展開で人材の必要数が急拡大した結果，一層 人材が不足しているという状況です。一方では NEET (Not in Education, Employment or Training) という本来 英国発のアクロニム (頭字語) が日本の社会問題となる ほど，若年層の勤労に対する意識は変わってきてしまっ ているようで，製造業での人材不足は深刻な問題となっ ています．バブル経済期に㖩かれた製造業 $=3 \mathrm{~K}$ （污い， きつい，暗い）職場での人不足眯念が，十数年経って違 う形で再燃しています。製造業は魅力ある職場造りを求 められています。

最近，日本のホンダに入社した人の入社動機を聞くと， ホンダでこういうことが是非やりたいという明確なもの が少なくて，「寄らば大樹」的な考えが多いようです. ASIMO を開発したいとか, Honda Jet を設計したいなど の表に出た派手なことへの興味はあっても，製造現場の こんな仕事がしたいとか生産設備を開発設計したいなど という意向は大変薄くなっています. ホンダの企業色に やんちゃなトンガリ色が薄れてしまったことを自省しな ければいけないのかと思いますが，先に述べたオハイオ 工場での新入社員の例と比較すると学生時代の教育体系, カリキュラムにも起因するのではないかとも思います。 製造業，製造現場を魅力あるものとして，面白いと思っ てもらえる努力と工夫を今後も続けていきたいと思いま す. 